$\begin{array}{llll}\text { ANA BRASILEIRO, MD } & \text { RITA RIBEIRO, MD } & \text { PEDRO EDUARDO SILVA, MD } & \text { ANA FIDALGO, MD } \\ \text { Department of Dermatology, } & \text { Department of Internal Medicine, } & \text { Department of Internal Medicine, Hospital } & \text { Department of Dermatology, } \\ \text { Hospital S. António dos Capuchos, } & \text { Hospital S. António dos Capuchos, } & \text { S. António dos Capuchos, Centro Hospita- } & \text { Hospital S. António dos Capuchos, } \\ \text { Centro Hospitalar de Lisboa Central, } & \text { Centro Hospitalar de Lisboa Central, } & \text { lar de Lisboa Central, Lisbon, Portugal } & \text { Centro Hospitalar de Lisboa Central, } \\ \text { Lisbon, Portugal } & \text { Lisbon, Portugal } & \text { Lisbon, Portugal }\end{array}$

\title{
Stellate ulceration in a nonuremic patient
}

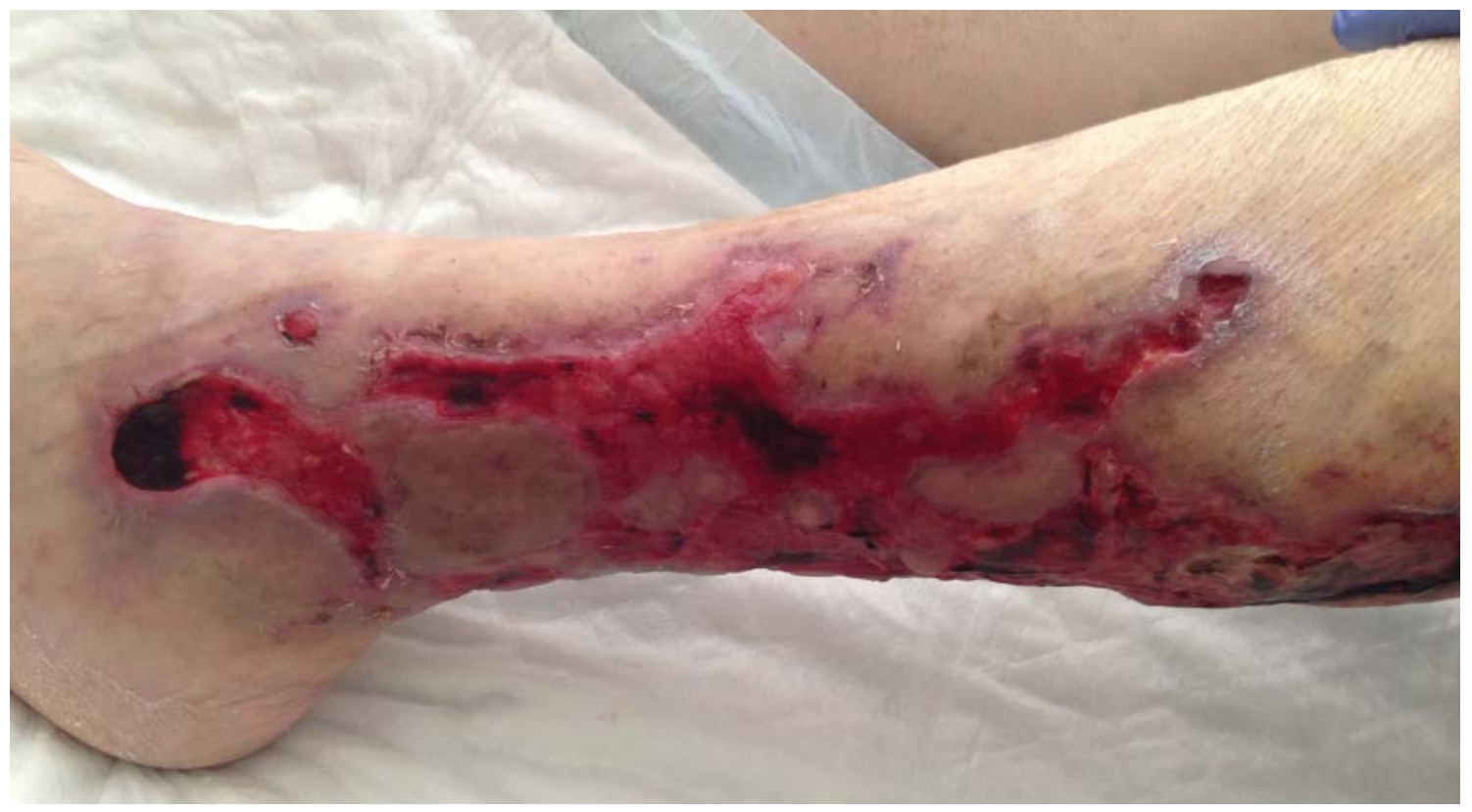

FIGURE 1. The patient's left lower leg had a star-shaped ulceration that included large areas of granulation tissue and necrotic tissue.
A
64-YEAR-OLD MAN WAS admitted for extensive painful ulceration of the left lower leg (Figure 1) that occurred after a fall and that had worsened over the last 4 months.
His medical history included hyperuricemia, hy- pertension, and type 2 diabetes mellitus. He had no known cardiac or renal disease.
Results of initial laboratory testing showed the fol- lowing:
- Hemoglobin $10.9 \mathrm{~g} / \mathrm{dL}$ (reference range 13.5-17.5); red blood cells were normocytic and normochromic
- White blood cell count $10.2 \times 10^{9} / \mathrm{L}(4.5-11.0)$
- Neutrophil count $9.11 \times 10^{9} / \mathrm{L}(2.0-8.5)$
- C-reactive protein $259 \mathrm{mg} / \mathrm{L}(<5)$
- Creatinine, urea, sodium, potassium, calcium, and phosphate were within normal limits.
Doppler ultrasonography of the legs showed mild diffuse atheromatous arterial disease without signifi- cant blockage of blood flow, in addition to mild bilat- eral venous insufficiency.
Cutaneous biopsy showed intravascular calcium deposition in the hypodermis (Figure 2) and reticu- lar dermis, erythrocyte extravasation in the superficial dermis, and epidermal necrosis, thus establishing the diagnosis of nonuremic calciphylaxis. The vascular oc- clusion with spreading necrosis gave the characteristic stellate appearance.
Aside from diabetes, our patient had none of the conditions usually associated with nonuremic cal- ciphylaxis-namely, hyperparathyroidism, previous corticosteroid therapy, warfarin use, connective tissue disease, or malignancy.

doi:10.3949/ccjm.82a.14176 


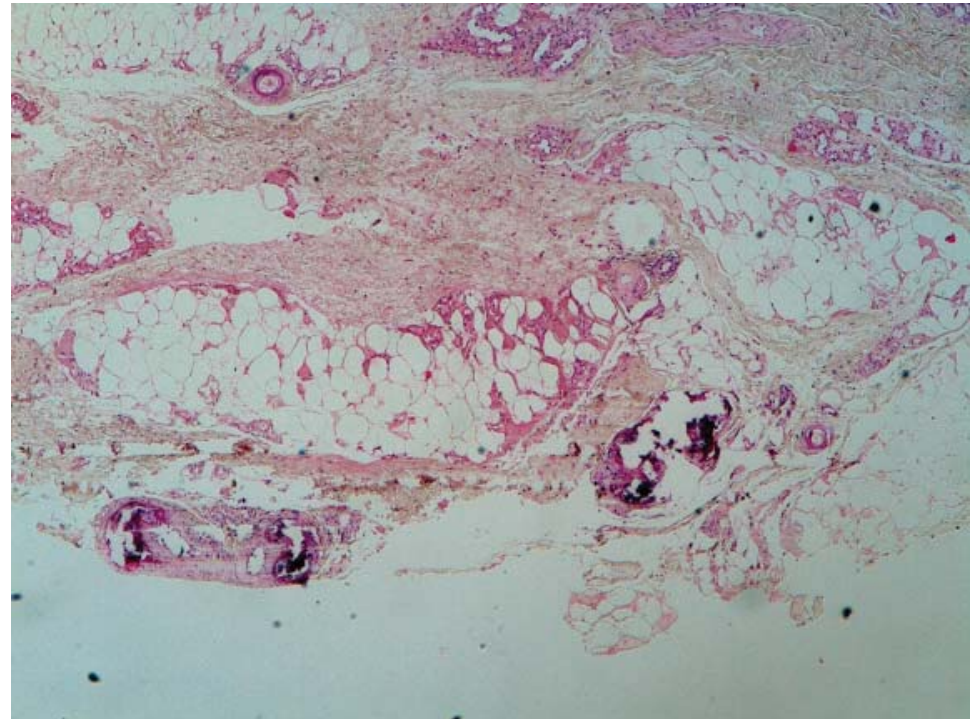

FIGURE 2. Histologic study showed intravascular calcium deposition in the hypodermis (hematoxylin and eosin, $\times 40$ ).

\section{A POORLY UNDERSTOOD SMALL-VESSEL VASCULOPATHY}

Calciphylaxis is a poorly understood smallvessel vasculopathy, most often associated with end-stage renal disease, with a prevalence of $1 \%$ to $4 \%$ in patients on dialysis. ${ }^{1}$ It carries a

Cutaneous biopsy showed intravascular calcium deposition in the hypodermis and the reticular dermis high risk of death, most often from sepsis.

The cause is still unclear, but several conditions have been implicated, including primary hyperparathyroidism, malignancies, alcoholic liver disease, connective tissue disease, and diabetes. ${ }^{2}$

Making the diagnosis may be challenging, especially in nonuremic patients. It is a rare condition, the presentation is not always typical, and it can occur with fully normal kidney function and normal indicators of calcium and phosphate metabolism.

The differential diagnosis includes:

- Vasculitis, either primary or secondary to an autoimmune disorder such as rheumatoid arthritis, systemic lupus erythematosus, or cryoglobulinemia

\section{REFERENCES}

1. Van Hattem S, Bootsma AH, Thio HB. Skin manifestations of diabetes. Cleve Clin J Med 2008; 75:772-777.

2. Nigwekar SU, Wolf M, Sterns RH, Hix JK. Calciphylaxis from nonuremic causes: a systematic review. Clin J Am Soc Nephrol 2008; 3:1139-1143.

3. Lee JL, Naguwa SM, Cheema G, Gershwin ME. Recognizing calcific uremic arteriolopathy in autoimmune disease: An emerging mimicker of vasculitis. Autoimmun Rev 2008; 7:638-643.
- Peripheral vascular disease

- Other inflammatory conditions such as pyoderma gangrenosum and panniculitis

- Infections such as cellulitis and necrotizing fasciitis

- Iatrogenic disorders such as warfarin necrosis and early-stage nephrogenic systemic fibrosis. ${ }^{3,4}$

The current approach to treatment is multidisciplinary and is based only on case reports and small case series, since no randomized prospective trial has been done. The goal is optimal control of calcium and phosphate homeostasis and correction of hypercoagulability. ${ }^{5}$ Available data ${ }^{4,5}$ support appropriate wound care and surgical debridement. 4,5 Intravenous sodium thiosulfate is the most widely used medical treatment and can be given regardless of the level of renal function. Resolution rates have been greater than $90 \%$ in patients with normal renal function, whereas improvement in cutaneous ulcers and pain has been observed in $70 \%$ of hemodialysis patients. ${ }^{4}$ However, it does not reduce the associated mortality rate. ${ }^{4}$

Awareness of nonuremic calciphylaxis and a high index of suspicion are needed when any patient presents with a leg ulcer and no clear cause. It should be considered in the differential diagnosis of leg ulcer in patients with chronic renal failure even if they have risk factors for more common causes of ulcers, and even occasionally in patients such as ours without chronic kidney disease or other risk factors for this condition.

\section{OUR PATIENT'S MANAGEMENT}

The patient developed profuse diarrhea, and infection with Clostridium difficile was confirmed. Despite treatment with metronidazole and vancomycin, he died several days later. No treatment directed to calciphylaxis was ever started because of the patient's unstable condition during the entire hospitalization.
4. Wollina U. Update on cutaneous calciphylaxis. Indian J Dermatol 2013; 58:87-92.

5. Ross EA. Evolution of treatment strategies for calciphylaxis. Am J Nephrol 2011; 34:460-467.

ADDRESS: Ana Brasileiro, MD, Department of Dermatology, Hospital S. António dos Capuchos, Centro Hospitalar de Lisboa Central, Alameda Santo António dos Capuchos, 1169-050 Lisbon, Portugal; e-mail: afmbrasileiro@gmail.com 